\title{
Monika Chorab
}

Uniwersytet Jagielloński

\section{Funkcjonowanie studentów we współczesnej rzeczywistości uniwersyteckiej}

\begin{abstract}
Wprowadzenie
Młodość to złożony okres zmian, które prowadzą do osiągnięcia statusu człowieka dorosłego oraz pełnienia ról społecznych z nim związanych. W obecnej rzeczywistości jest to zjawisko długotrwałe, obejmujące zróżnicowane grupy młodzieży. Młodość jest okresem życia między dzieciństwem i dorosłością. Podstawowym celem młodości jest rozwój osobowości, charakteru i zdolności (w tym intelektualnych i akademickich). Głównym zadaniem jest pozostawienie za sobą wcześniejszego etapu życia i wejście w dorosłość jako pewna siebie i niezależna osoba, która odnalazła swoje miejsce w społeczeństwie, by w sposób odpowiedzialny realizować role rodzinne, zawodowe i wspólnotowe ${ }^{1}$. Młodość nie kończy się wraz z zakończeniem dorastania i okresu adolescencji. Dla wielu młodych ludzi kres młodości i tym samym początek dorosłego życia wyznacza dopiero ukończenie studiów wyższych. Upowszechnienie studiów wyższych pozwoliło na wyodrębnienie kategorii młodzieży studenckiej, której specyfika kształtuje przyszły charakter społeczeństwa wiedzy.
\end{abstract}

\section{Metodologia badań własnych}

Artykuł jest komunikatem $\mathrm{z}$ badań przeprowadzonych na terenie czterech polskich uniwersytetów. Celem artykułu jest ocena studentów jako grupy społecznej funkcjonującej we współczesnej rzeczywistości uniwersyteckiej oraz - co za tym idzie - poznanie zakresu i specyfiki zjawisk składających się na współczesny proces studiowania. Podstawą artykułu jest poszukiwanie odpowiedzi na tworzące problem badawczy pytanie, jakie cechy charakteryzują młodzież studencką we współczesnej rzeczywistości uniwersyteckiej oraz

1 M. Gibbons, The Self-Directed Learning Handbook. Challenging Adolescent Students to Excel, Jossey-Bass, San Francisco 2002, s. 2-3. 
jak obecnie przebiega proces studiowania. Ocena grupy społecznej studentów została dokonana na podstawie wyników badań przeprowadzonych na terenie czterech najstarszych polskich uniwersytetów: Uniwersytetu Jagiellońskiego, Uniwersytetu Wrocławskiego, Uniwersytetu Warszawskiego i Uniwersytetu im. Adama Mickiewicza w Poznaniu ${ }^{2}$. Badania rozpoczęto $\mathrm{w}$ roku akademickim 2012/2013 (w semestrze letnim) oraz kontynuowano w roku akademickim 2013/2014 (w semestrze zimowym). Badania przeprowadzono z zastosowaniem metodologii badań ilościowych i jakościowych. Zastosowano takie narzędzia, jak: kwestionariusz ankiety, kwestionariusz wywiadu indywidualnego oraz esej. W badaniach udział wzięło 1048 studentów oraz 17 pracowników naukowych. Celem badań była ocena przebiegu, zakresu i specyfiki zjawisk składających się na współczesny przebieg studiowania dokonana z perspektywy podejmowanych i realizowanych przez studentów ról edukacyjnych i pozaedukacyjnych, warunkowanych współczesną rzeczywistością uniwersytecką.

\section{Grupa społeczna studentów - cechy integrujące i różnicujące}

Młodzież studencką wyróżnia i charakteryzuje odrębność, poczucie wspólnoty wewnątrzgrupowej i organizacja wewnętrzna, co prowadzi do opisu współczesnego charakteru polskich studentów z uwzględnieniem cech wspólnych i różnic wewnątrzgrupowych. Studentów lączy etos, czyli zespół norm moralno-obyczajowych typowych dla tej specyficznej grupy społecznej3. Młodzież studencka to osoby pełnoletnie, które z reguły rozpoczynają kształcenie w wieku 19 lat, czasem później, a kończą zwykle w wieku 24 lat. Częstym zjawiskiem jest wydłużenie czasu studiów, które kontynuowane mogą być nawet w wieku 30 lat, szczególnie gdy osoba decyduje się na podjęcie trzeciego stopnia kształcenia, kończącego się uzyskaniem stopnia naukowego doktora. Młodzież studencką łączy status osoby uczestniczącej w procesie kształcenia wyższego. Studentów z reguły charakteryzuje niesamodzielność ekonomiczna, która przejawia się pod postacią pomocy finansowej otrzymywanej z różnych źródeł, najczęściej od rodziców i ze środków stypendialnych. Należy wskazać na charakteryzującą młodzież studencką względną niesamodzielność społeczną, wynikającą z tego, że podlega ona wpływom socjalizacyjnym i wychowawczym, dzięki którym uczy się i przygotowuje do realizacji przyszłych ról społecznych4.

2 Badania przeprowadzone zostały na potrzeby obronionej w czerwcu 2014 roku w Instytucie Pedagogiki UJ pracy doktorskiej pt. Studiowanie z perspektywy ról spotecznych studentów w toku stawania się rzeczywistości uniwersyteckiej. Praca została napisana pod kierunkiem prof. dr hab. Janiny Kostkiewicz. Recenzentami pracy byli prof. dr hab. Marian Śnieżyński oraz prof. dr hab. Stanisław Palka. Rozprawa oraz zaprezentowane w niniejszym artykule wyniki badań nie byly wcześniej publikowane.

3 B. Ostafińska-Molik, Studenci - dziś $i$ wczoraj. Refleksja o etosie, w: Student na wspótczesnym uniwersytecie. Ideaty i codzienność, red. D. Pauluk, Impuls, Kraków 2010, s. 175. 
Młodzież studencką integruje nauka jako podstawowa aktywność okresu młodości. Nauka jako element kultury stanowi wartość, generuje inne wartości oraz prowadzi do rozwoju osób z nią związanych ${ }^{5}$. Oprócz nauki studentów łączą wspólne nurty aktywności życiowej, sposoby spędzania wolnego czasu, wzory zachowania oraz korzystanie ze wspólnej przestrzeni społecznej ${ }^{6}$.

\section{Charakterystyka studentów uniwersytetu przez pryzmat podejmowania studiów I, II I III stopnia}

Przedstawione powyżej ogólne cechy charakterystyczne dla młodzieży studenckiej prowadzą do pytania o to, kim jest współczesny student. Opisane cechy charakteryzują studentów dziennych, studiujących na studiach licencjackich i magisterskich. Należy się bliżej przyjrzeć doktorantom, którzy podobnie jak studenci studiów I i II stopnia realizują role edukacyjne oraz naukowe. Tekst Deklaracji Bolońskiej dzieli proces studiowania na trzy możliwe stopnie. Tym samym za członków grupy społecznej studentów uznaje uczestników studiów licencjackich, magisterskich oraz doktoranckich. W zgodzie z Deklaracją Bolońską pozostaje obowiązujący tekst ustawy o szkolnictwie wyższym, który definiuję studenta jako osobę kształcącą się na studiach wyższych. Ustawa uznaje doktoranta za uczestnika studiów doktoranckich i tym samym przyznaje mu status studenta $^{7}$. W dyskusji na temat charakteru młodzieży akademickiej oraz miejsca doktorantów ciekawe podejście reprezentuje Florian Znaniecki. Poszukując definicji kulturowej, autor opisywał studentów uczelni jako "odrębną klasę logiczną, zawieszoną w kompleksie kulturowym, który tworzy uczelnia"s. Poglądy autora potwierdzają tezę o traktowaniu doktorantów jako współczłonków grupy studenckiej, gdyż podobnie jak studenci uczestniczą oni w kompleksie kulturowym danej uczelni.

Zwrócenie uwagi na trzy stopnie kształcenia wyższego, studia I, II i III stopnia, pozwala wydobyć podstawową cechę współczesnych studiów wyższych, jaką jest złożoność. Wskazana złożoność przejawia się występowaniem kilku faz życia studenckiego, które najprościej można określać w perspektywie kolejnych trzech stopni studiowania. Specyfika studiów licencjackich, magisterskich i doktoranckich wynika z różnic w obowiązkach studenckich oraz jest związana z podejmowaniem i realizacją różnych życiowych ról społecznych. Kazimierz Jaskot, analizując społeczno-edukacyjne cechy życia studenckiego,

5 J. Kostkiewicz, Nauka i wolność - wartości fundujące uniwersytet, w: Uniwersytet $i$ wartości, red. J. Kostkiewicz, Impuls, Kraków 2007, s. 15.

6 E. Trubiłowicz, Studenci i ich świat: od stanu wojennego do Unii Europejskiej, Wyd. KUL, Lublin 2006, s. 33.

7 Ustawa z dnia 18 marca 2011 r. o zmianie ustawy - Prawo o szkolnictwie wyższym, ustawy o stopniach naukowych oraz o stopniach i tytule w zakresie sztuki oraz o zmianie niektórych inny ustaw, Art. 2.1 pkt 18k, 181 . 
wydzielił trzy fazy studiowania. Fazę pierwszą określił jako okres przygotowania do roli studenta oraz przystosowania do zastanych wzorów społeczno-kulturowych. Faza druga to czas aktywności w grupach studenckich, czas pełnej realizacji obowiązków wynikających $\mathrm{z}$ roli studenta. $\mathrm{W}$ fazie trzeciej młodzi ludzie skupiają się na ukończeniu studiów, przyszłej pracy zawodowej, życiu rodzinnym i społecznym?.

Podstawą funkcjonowania młodego człowieka, który w zgodzie ze specyfiką wieku podejmuje studia wyższe (w tym wypadku uniwersyteckie), jest działalność, której celem jest realizowanie obowiązków wynikających z bycia studentem. W literaturze przedmiotu studenci są określani w kategorii dużej, zróżnicowanej pod względem cech członków oraz wciąż ekskluzywnej i zamkniętej grupy społecznej, wyodrębnionej ze złożonej populacji młodzieży. W ramach zróżnicowanej grupy społecznej studentów funkcjonują liczne mniejsze grupy, tworzone ze względu na rodzaj uczelni, wydział, instytut, kierunek, specjalność, rok studiów itp. Na potrzeby prowadzonych badań z grupy studenckiej zostali wybrani studenci uniwersytetu. Analizę rozpoczynam od charakterystyki cech studentów uniwersytetu, z punktu widzenia członków wspólnoty akademickiej: studentów i pracowników naukowych.

\section{Cechy współczesnych studentów w opinii uczestników rzeczywistości uniwersyteckiej}

Badani studenci i pracownicy naukowi określają studentów uniwersytetu jako specyficzną i zróżnicowaną zbiorowość społeczną ${ }^{10}$, która jest wyodrębniona z populacji młodzieży ze względu na:

1. Wiek - który w większości przypadków można określić na 19-25 lat. Poza tą grupą wiekową znajdują się studenci, którzy przedłużają lub odraczają czas studiów, a także doktoranci jako studenci studiów III stopnia. Badani jako wiek graniczny dla bycia studentem podali 25 lat. Badani zdają się nie postrzegać doktorantów jako studentów. Doktoranci zwykle mają własne kursy, stąd nie uczestniczą w zajęciach dydaktycznych dla studentów studiów I i II stopnia. Co więcej to, że prowadzą zajęcia, determinuje postrzeganie ich jako pracowników naukowych, a nie studentów III stopnia kształcenia ${ }^{11}$.

2. Obowiązki i zadania - które zogniskowane są wokół podstawowego celu wieku studiów, jakim jest zdobycie wykształcenia wyższego, w tym wypadku uniwersyteckiego. Badani studenci mają świadomość funkcjonowania specyficznego dla każdego kierun-

9 K. Jaskot, Grupy studenckie. Studium pedagogiczne grup dziekańskich, Wyd. Nauk. US, Szczecin 1996, s. 31.

10 Case 10, 15. Odnośniki ze słowem „case” dotyczą numerów wywiadów przeprowadzonych na potrzeby rozprawy doktorskiej: M. Chorab, Studiowanie $z$ perspektywy ról społecznych studentów $w$ toku stawania się rzeczywistości uniwersyteckiej, Instytut Pedagogiki UJ, Kraków 2014.

11

Case 10, 28. 
ku kształcenia zestawu obowiązków studenckich, które są konieczne do utrzymania indywidualnego statusu oraz prowadzą do zdobycia dyplomu. Podejmują je w sposób bezkrytyczny, co może świadczyć o tendencji do podporządkowania się regułom rzeczywistości uniwersyteckiej lub świadomości zasadności obowiązków i ich wagi w procesie kształcenia, które aby było skuteczne, musi mieć charakter ukierunkowany ${ }^{12}$.

3. Role społeczne pełnione przez studentów - które wynikają z obowiązków i zadań oraz stanowią ich potwierdzenie. Studenci widzą specyficzny zestaw ról społecznych, które odróżniają ich od innych przedstawicieli młodzieży i wynikają ze specyfiki studiowania i wspomnianego zestawu podejmowanych i realizowanych (z różną częstotliwością i zaangażowaniem) obowiązków i zadańn ${ }^{13}$.

Wyodrębniona w zgodzie $\mathrm{z}$ wymienionymi kryteriami grupa społeczna studentów to grupa duża ${ }^{14}$, która wciąż się rozrasta ze względu na zwiększenie się dostępności studiowania oraz zróżnicowana ${ }^{15}$. Jak wskazują badani, rzeczywistość uniwersytecką tworzy ogromna liczba młodych ludzi. Są oni studentami, choć też pracownikami, dziećmi, rodzicami czy małżonkami ${ }^{16}$. W ramach jednego kierunku, a nawet roku studiów, możemy znaleźć pełen przekrój społeczny ${ }^{17}$, który jest szczególnie wyraźny, gdy analizuje się pochodzenie studentów. Jeszcze paręnaście lat temu na studiowanie mogły sobie pozwolić osoby z miast, rzadziej z miasteczek, a osób pochodzących z wiosek było zdecydowanie mniej. Obecnie studenci pochodzą z różnych miejscowości, w tym z miast, miasteczek, mniej lub bardziej oddalonych od miejsca kształcenia $\mathrm{wsi}^{18}{ }^{18}$. Ważnym kryterium różnicującym jest indywidualna motywacja studenta do podjęcia studiów wyższych. Studenci uniwersytetu to grupa osób podejmujących naukę z różnych powodów i tym samym zróżnicowana ze względu na zaangażowanie w realizację obowiązków studenckich ${ }^{19}$.

Badani studenci i pracownicy dostrzegają ogromne zróżnicowanie studentów uniwersytetu. Na podstawie analizy materiału badawczego można wyróżnić takie kategorie różnicujące, jak: pochodzenie, podejmowane role zawodowe, rodzinne, wspólnotowe, zainteresowania, motywy podejmowania studiów wyższych, poczucie odpowiedzialności za studiowanie. Ważną kategorią są efekty kształcenia, które pozostają w związku z wymienionymi kategoriami i w sposób bezpośredni z nich wynikają.

$\mathrm{Z}$ efektami kształcenia pozostaje $\mathrm{w}$ związku czas poświęcany na realizację podejmowanych $\mathrm{w}$ ramach statusu studenta obowiązków studenckich, który również różnicuje

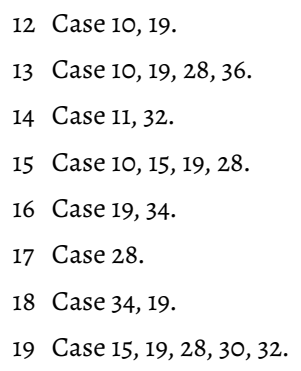


badanych studentów. Większość (22,8\% badanych) poświęca na realizację obowiązków studenckich 2-4 godziny dziennie, 20\%-4-6 godzin dziennie, 19,1\%-6-8 godzin dziennie, $16,6 \%$ - więcej niż 8 godzin dziennie, natomiast aż $21,4 \%$ poświęca na realizację obowiązków studenckich mniej niż 2 godziny dziennie. W sytuacji, gdy traktujemy rolę studenta jako podstawową dla wieku studiów, przeznaczanie 2-4 godzin dziennie na realizację obowiązków studenckich wydaje się być zdecydowanie za mało. Natomiast deklarowane przez $21,4 \%$ badanych mniej niż 2 godziny dziennie stawia pod znakiem zapytania możliwość uzyskania jakichkolwiek efektów kształcenia.

Studentów uniwersytetu różnicuje poziom zadowolenia z czasu, który poświęcają na realizację obowiązków studenckich. Większość studentów (53,1\%) uważa, że poświęca wystarczający czas na realizację obowiązków. Reszta badanych jest niezadowolona z ilości czasu, który poświęca na studiowanie. Analiza wskazuje na charakteryzującą część badanych świadomość co do faktu poświęcania na studiowanie zbyt małej ilości czasu, która uniemożliwia osiągnięcie satysfakcjonujących efektów kształcenia.

W opinii pracowników naukowych studentów jako grupę charakteryzuje poczucie tymczasowości, które przejawia się w działaniach. Studenci są w okresie przejściowym pomiędzy młodością a dorosłością. Zdecydowana większość studentów jest w pewnym zawieszeniu, gdyż skończyła już szkołę, są osobami dorosłymi, niemniej jednak jeszcze nie ponoszą pełnej odpowiedzialności za swoje życie, chociaż to też się oczywiście zmienia przez fakt, że studenci pracują i zakładają rodziny ${ }^{20}$. Poczucie tymczasowości jako cecha studentów zdaje się przynależeć do wieku studiów przez fakt odroczenia większości dorosłych ról społecznych i odpowiedzialności z nimi związanej. Część studentów podejmuje się ról zawodowych i rodzinnych, tym samym decydując się na wynikające z nich odpowiedzialność i obowiązki. Poczucie tymczasowości związane z odroczeniem odpowiedzialności może ulec generalizacji na wszystkie sfery aktywności, także na te związane z rolą studenta, która jest podstawowa dla wieku studiów. W takiej sytuacji młody człowiek przestaje brać odpowiedzialność za jakość realizacji obowiązków studenckich, a studia stają się tylko przerwą między młodością a dorosłym życiem. Zgeneralizowane poczucie tymczasowości może manifestować się potrzebą wydłużenia czasu studiów, przesunięcia momentu napisania i obrony pracy dyplomowej, zachowania statusu studenta tak długo, jak tylko jest to możliwe.

Mimo wewnętrznego zróżnicowania i braku jednorodności, homogeniczności grup studenckich, są one środowiskiem sprzyjającym integracji i współpracy członków, których łączy fakt podejmowania studiów wyższych i wspólna rzeczywistość uniwersytecka. To co obserwuje się wśród studentów, to bardzo szybkie wytwarzanie się więzi społecznych, gdzie już po pierwszych czy drugich zajęciach studenci zaczynają funkcjonować jako zorganizowana grupa. $Z$ integracją często związana jest współpraca. $\mathrm{Na}$ element współpracy wskazuje fakt dzielenia się materiałami, pożyczania kser i wymiany informa- 
cji na tematy organizacyjne. Jednak współpraca między członkami grupy studenckiej ma charakter ograniczony do działań mających na celu zrealizowanie podstawowych obowiązków, zapewniających utrzymanie statusu. Studenci współpracują, żeby zdać egzaminy, zaliczyć przedmioty przy mniejszym wysiłku, niż gdyby mieli się samodzielnie uczyć czy opracowywać materiały. Współpraca ogranicza się do wzajemnego informowania się i dzielenia się pracą. Nie obserwuje się takiego poziomu współpracy, jaki prowadziłby do inicjowania i podejmowania działań innowacyjnych, kreatywnych, zrobienia wspólnie czegoś nowego ${ }^{21}$. Współpraca między studentami jest ograniczona przez aspekt rywalizacji. Studenci mają świadomość, że na rynku pracy stają się konkurentami dla swoich przyjaciół i znajomych, koleżanek i kolegów z roku. Rywalizacja zaczyna się już na studiach, kiedy studenci liczą na siebie, ucząc się, zdając egzaminy i walcząc o stypendia naukowe, które nie są za wysokie, ale w pewnym stopniu motywują do rywalizacji ${ }^{22}$. Pracownicy naukowi obserwują fakt indywidualnego podejścia do studiowania. Jak wskazują, kiedyśs studenci woleli pracować grupowo, teraz wolą indywidualnie. Jedyną akceptowalną przez studentów pracą grupową jest praca w parach. Jeśli pracują w większych grupach, to raczej dzielą się i każdy robi swoja częśćéc. Studenci są coraz bardziej skupieni na swoim rozwoju, co można obserwować na egzaminach, na których coraz mniej ściągają od siebie, co kiedyś było nagminne ${ }^{24}$. Powyższe zjawisko ma charakter pozytywny i wskazuje na wzrost świadomości studentów i może większą uczciwość, ale jest również związane z zanikiem wspólnoty studenckiej, wzajemnego zaufania udzielających sobie wsparcia i utrzymania statusu osób.

W zdecydowanej większości pracownicy naukowi wskazują, że studenci uniwersytetu są grupą dużą, a nawet za dużą, w której gubi się odpowiedzialność za przebieg studiów, gdyż w tak dużej grupie są w stanie przetrwać nawet osoby nieustannie nieprzygotowane. Dla zbyt dużej grupy studenckiej studiowanie stało się czymś pospolitym, a student- studentem masowym, który niczym się nie wyróżnia w stosunku do innych przedstawicieli populacji młodzieży. Studenci uniwersytetu powinni według teorii różnić się od innych młodych ludzi. Jednak nie do końca tak jest, że można ich odróżnić od studentów innych uczelni, czy nawet od innych młodych ludzi ${ }^{25}$. Pojawienie się masowego kształcenia uniwersyteckiego prowadzi do stanu, w którym duża część studentów (nawet do 50\%) jest nieprzystosowana do warunków rzeczywistości uniwersyteckiej i w ogóle nie powinna studiować. Wskazany odsetek studentów charakteryzuje brak zainteresowań, brak ciekawości i pasji dowiadywania się czegoś nowego oraz brak celów w przebywaniu na uniwersytecie. Chodzi im tylko o to, aby skończyć studia i uzyskać dyplom. Co za tym idzie, wska-

\footnotetext{
21 Case 28, 29, 38.

22 Case 31.

23 Case 45, 38.

24 Case 31.

25 Case 30, 32.
} 
zany masowy student jest $\mathrm{w}$ swoim studiowaniu mniej samodzielny i dojrzały, a bardziej nieśmiały, co przejawia się w niechęci do zadawania pytań i wyjaśniania wątpliwości ${ }^{26}$. Mimo problemu, jakim jest spadek jakości kształcenia w sytuacji masowości edukacji, na uniwersytecie można odnaleźć większy niż na innych uczelniach odsetek młodzieży oczytanej, zmotywowanej do rozwoju i charakteryzującej się wyższym poziomem wykształcenia. Na uniwersytet na ogół przychodzą studenci lepsi. W opinii pracowników naukowych studentów uniwersytetu $\mathrm{w}$ stosunku do studentów innych uczelni charakteryzuje pracowitość, ambicje zawodowe i zdolności intelektualne ${ }^{27}$. W grupie studentów uniwersytetu badani wskazują 10\% studentów wyrastających ponad przeciętną, która w przypadku uniwersytetu jest wyższa niż w w przypadku innych szkół wyższych. Są to studenci najlepsi, którzy przychodzą na studia oczytani. Umieją zadawać pytania, ponieważ są ciekawi. Zajęcia są dla nich momentem, w którym mogą rozmawiać o tym, co już wiedzą, i prosić o wskazówki na temat tego, czego jeszcze nie wiedzą ${ }^{28}$. Masowość jako cecha współczesnej grupy studenckiej i szerzej kształcenia wyższego determinuje jakość kształcenia, która w opinii nauczycieli akademickich sukcesywnie się pogarsza.

Zauważalną cechą studentów jest również zwiększony pośpiech, wynikający z braku czasu. Studenci w swoim życiu robią bardzo dużo, ale bez analizy, bez wyciągania wniosków. Współcześni studenci to bardzo zapracowani ludzie, często studiują na dwóch lub więcej kierunkach, większość pracuje albo odbywa staże, przez co nie mają czasu dla siebie i własnego rozwoju. Trochę balansują na krawędzi, próbując wywiązać się z wszystkich obowiązków, które wypełniają byle jak, byle tylko zdać i byle nie zostać wyrzuconym ${ }^{29}$. Aktywność pozauniwersytecka i brak czasu przyczyniły się do tego, że studenci przestali chodzić na wykłady ${ }^{30}$. Pracownicy naukowi nie krytykują faktu podejmowania przez studentów aktywności pozanaukowej, rodzinnej czy zawodowej. Zdają się pozytywnie oceniać zaradnych, pracujących i zakładających rodzinę studentów. Nie zmienia to jednak faktu, że widzą związek między podejmowaniem ról pozaedukacyjnych a przebiegiem procesu kształcenia i ubolewają nad ograniczoną obecnością studentów, szczególnie na zajęciach nieobowiązkowych i wykładach, oraz zmniejszającą się jakością kształcenia w sytuacji umasowienia.

W opinii pracowników naukowych studenci nie tylko nie chodzą na wykłady, ale również ograniczają do minimum kontakty z wykładowcami, co prowadzi do zupełnego zaniku relacji mistrz-uczeń. Okazją do spotkania z pracownikiem naukowym jest dyżur, który z zasady i w zgodzie z regulaminem ma charakter regularny, a terminy i miejsca dyżurów są podawane do informacji studentów. Studenci mają również możliwość wcześniejszego

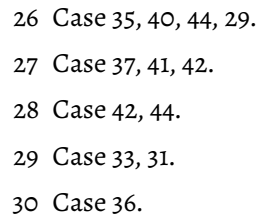


kontaktu telefonicznego czy mailowego w celu umówienia się w terminie dyżuru lub w innym im odpowiadającym. Mimo wydawałoby się ułatwionego dostępu do pracowników naukowych, studenci rzadko przychodzą na dyżury, a kontakty z wykładowcami ograniczają do sali, w której prowadzone są zajęcia oraz ewentualnego kontaktu elektronicznego, który często im wystarcza. W ciągu semestru nie przychodzą w ogóle. Zwiększone zainteresowanie jest tuż przed sesją egzaminacyjną i w jej czasie, kiedy konsultacje trwają tyle, ile mogłyby trwać przez cały semestr, gdyby studenci byli obecni, a do prowadzących często są nawet kolejki $i^{31}$. Studenci zwykle przychodzą na dyżury i konsultacje z czysto praktycznych powodów, z problemami technicznymi, organizacyjnymi, administracyjnymi - pytają się o zagadnienia do egzaminu, chcą umówić się na egzamin czy zaliczenie, przepisać ocenę. W czasie dyżurów zdarzają się również kwestie natury osobistej, gdy student ma problem. Zdarzają się też studenci, którzy przychodzą po poradę (np. jakie studia drugiego stopnia wybrać, jak załatwić jakieś sprawy itp.). Czasami na dyżurach pojawiają się osoby zainteresowane sprawami naukowymi, które chcą porozmawiać, podzielić się swoimi wątpliwościami czy spostrzeżeniami o charakterze naukowym. Zdarza się to niezwykle rzadko, a takich studentów na długo się zapamiętuje. Sprawy merytoryczne zdarzają się, gdy studenci pracują nad jakimś zagadnieniem, tematem w ramach pracy zaliczeniowej czy nad pracą dyplomową ${ }^{32}$. Najczęściej z nauczycielami akademickimi kontaktują się studenci piszący prace dyplomowe, licencjacie, magisterskie lub doktorskie, którym wykładowcy poświęcają większość czasu na konsultacjach poza zajęciami. Seminarzyści przychodzą najczęściej w celu poradzenia się co do pracy i z pytaniem, gdzie znaleźć materiały. Pojawiają się też bardziej szczegółowe problemy w ramach pisanej pracy33. Badani pracownicy naukowi są zaniepokojeni ciągle zmniejszającą się aktywnością w grupie studenckiej i tym, że studenci coraz rzadziej szukają z nimi kontaktu, nie tylko w sprawach formalnych, ale też naukowych. Wskazują na zanik relacji uczeń-mistrz, który wiążą ze spadkiem jakości kształcenia w sytuacji masowości. Pracownicy naukowi starają się reagować w odpowiedzi na zanik aktywności studentów, którzy przestali szukać z nimi kontaktu naukowego. Przykładowo, konsultacje często odbywają się w trakcie zajęć czy przed lub zaraz po ${ }^{34}$, a studenci są wprost motywowani do obecności, zadawania pytań i rozmów o problemach naukowych.

W opinii pracowników naukowych studenci myślą pragmatycznie, są zdecydowani i lepiej wiedza, co chcieliby robićs ${ }^{35}$. Studenci dążą do własnego rozwoju, realizacji indywidualnych zainteresowań, co przejawia się podejmowaniem (w przypadku 19,1\% badanych)

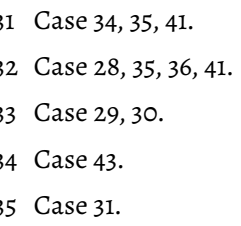


więcej niż jednego kierunku kształcenia oraz realizacją grantu badawczego (w przypadku $6,9 \%$ respondentów).

Wskazana świadomość własnych zainteresowań i potrzeb naukowych powoduje, że grupy studenckie są bardziej roszczeniowe, co przejawia się w manifestowanych przez młodych ludzi wymaganiach co do formy, metod prowadzonych zajęć i zasad zaliczenia. Badani pracownicy naukowi wskazują, że studenci zachowują się tak, jakby dyplom im się należał w sytuacji, gdy wykonają konkretne czynności. Postawie roszczeniowej towarzyszy mniej formalny sposób zachowania się studentów, który często prowadzi do zaniku postrzegania nauczyciela akademickiego jako autorytetu naukowego i upadku wychowawczej funkcji uniwersytetu. Studenci zachowują się w sposób mniej formalny niż dawniej. Dawniej był dużo większy dystans między studentem a uczącym ${ }^{36}$.

Grupę społeczną studentów uniwersytetu można również opisywać i oceniać przez pryzmat uzyskanej średniej ocen oraz poziomu zadowolenia z uzyskanej średniej. Przeważająca większość badanych studentów $(45,7 \%)$ w poprzedzającym roku akademickim uzyskała średnią 4,5-5, 35,7\% uzyskało średnią 4-4,5, natomiast 18,6\% - niższą niż 4. Deklarowana przez studentów średnia ocen, uzyskana w poprzedzającym roku akademickim, wydaje się być obiektywnie wysoka. Fakt, że wysokiej średniej ocen towarzyszy niewielka ilość czasu przeznaczona na codzienną realizację obowiązków studenckich (w przypadku 21,4\% badanych mniej niż 2 godziny dziennie), świadczy o wyraźnym spadku jakości kształcenia, co manifestuje się w zmniejszonych wymaganiach w stosunku do grupy studenckiej tworzonej w atmosferze masowości.

W związku z uzyskiwaną indywidualnie średnią ocen pozostaje kwestia poziomu zadowolenia $\mathrm{z}$ indywidualnej średniej ocen. Przeważająca większość badanych (73,9\%) jest zadowolona z uzyskanej średniej ocen. Jedynie $26,2 \%$ wyraża swoje niezadowolenie.

\section{Charakterystyka studiowania we współczesnej rzeczywistości uniwersyteckiej}

W toku studiowania studenci podejmują wiele obowiązków. Studiowanie jest zależne od częstotliwości podejmowania obowiązków oraz zaangażowania w ich realizację.

Szczegółowy liczbowy i procentowy wykaz deklaracji studentów (studiów I, II, III stopnia), dotyczących częstotliwości podejmowania obowiązków studenckich, ukazuje również tabela 1 . 
Tabela 1.Częstotliwość podejmowania obowiązków studenckich przez studentów uniwersytetu $(\mathrm{N}=1048)$

\begin{tabular}{|c|c|c|c|c|c|c|c|}
\hline \multirow[b]{2}{*}{ Obowiązki studenckie } & \multicolumn{7}{|c|}{ Częstotliwość podejmowania obowiązków studenckich } \\
\hline & $\mathrm{N} / \%$ & nigdy & rzadko & czasami & regularnie & $\begin{array}{c}\text { suma } \\
\text { (bez braków) }\end{array}$ & brak \\
\hline \multirow{2}{*}{ Obecność na wykładach } & $\mathrm{N}$ & 42 & 128 & 255 & 557 & 982 & 66 \\
\hline & $\%$ & 4,3 & 13,0 & 26,0 & 56,7 & 100 & 6,3 \\
\hline \multirow{2}{*}{ Obecność na ćwiczeniach } & $\mathrm{N}$ & 29 & 10 & 49 & 890 & 978 & 70 \\
\hline & $\%$ & 3,0 & 1,0 & 5,0 & 91,0 & 100 & 6,7 \\
\hline \multirow{2}{*}{ Uczestnictwo w zajęciach obowiązkowych } & $\mathrm{N}$ & 3 & 11 & 28 & 927 & 969 & 79 \\
\hline & $\%$ & 0,3 & 1,1 & 2,9 & 95,7 & 100 & 7,5 \\
\hline \multirow{2}{*}{ Uczestnictwo w zajęciach dodatkowych } & $\mathrm{N}$ & 160 & 289 & 387 & 139 & 975 & 73 \\
\hline & $\%$ & 16,4 & 29,6 & 39,7 & 14,3 & 100 & 7,0 \\
\hline \multirow{2}{*}{ Uczestnictwo w zajęciach e-lerningowych } & $\mathrm{N}$ & 458 & 281 & 143 & 88 & 970 & 78 \\
\hline & $\%$ & 47,2 & 29,0 & 14,7 & 9,1 & 100 & 7,4 \\
\hline \multirow{2}{*}{ Zadania zespołowe realizowane w ramach zajęć } & $\mathrm{N}$ & 101 & 205 & 293 & 372 & 971 & 77 \\
\hline & $\%$ & 10,4 & 21,1 & 30,2 & 38,3 & 100 & 7,3 \\
\hline \multirow{2}{*}{$\begin{array}{l}\text { Zadania indywidualne realizowane w ramach } \\
\text { zajęć }\end{array}$} & $\mathrm{N}$ & 47 & 79 & 283 & 564 & 973 & 75 \\
\hline & $\%$ & 4,8 & 8,1 & 29,1 & 58,0 & 100 & 7,2 \\
\hline \multirow{2}{*}{ Aktywny udział w zajęciach } & $\mathrm{N}$ & 12 & 130 & 407 & 424 & 973 & 75 \\
\hline & $\%$ & 1,2 & 13,4 & 41,8 & 43,6 & 100 & 7,2 \\
\hline \multirow{2}{*}{ Przygotowanie się do udziału w zajęciach } & $\mathrm{N}$ & 13 & 129 & 395 & 435 & 972 & 76 \\
\hline & $\%$ & 1,3 & 13,3 & 40,6 & 44,8 & 100 & 7,3 \\
\hline \multirow{2}{*}{ Przygotowanie się do kolokwiów, egzaminów } & $\mathrm{N}$ & 6 & 39 & 198 & 732 & 975 & 73 \\
\hline & $\%$ & 0,6 & 4,0 & 20,3 & 75,1 & 100 & 7,0 \\
\hline \multirow{2}{*}{ Uczestnictwo w wykładach otwartych } & $\mathrm{N}$ & 190 & 375 & 329 & 81 & 975 & 73 \\
\hline & $\%$ & 19,5 & 38,5 & 33,7 & 8,3 & 100 & 7,0 \\
\hline \multirow{2}{*}{$\begin{array}{l}\text { Uczestnictwo w dodatkowych kursach } \\
\text { i szkoleniach }\end{array}$} & $\mathrm{N}$ & 167 & 374 & 342 & 86 & 969 & 79 \\
\hline & $\%$ & 17,2 & 38,6 & 35,3 & 8,9 & 100 & 7,5 \\
\hline \multirow{2}{*}{ Czytanie obowiązkowej literatury naukowej } & $\mathrm{N}$ & 31 & 126 & 329 & 486 & 972 & 76 \\
\hline & $\%$ & 3,2 & 13,0 & 33,8 & 50,0 & 100 & 7,3 \\
\hline \multirow{2}{*}{ Czytanie nieobowiązkowej literatury naukowej } & $\mathrm{N}$ & 130 & 307 & 369 & 171 & 977 & 71 \\
\hline & $\%$ & 13,3 & 31,4 & 37,8 & 17,5 & 100 & 6,8 \\
\hline \multirow{2}{*}{ Korzystanie z czasopism naukowych } & $\mathrm{N}$ & 156 & 323 & 300 & 194 & 973 & 75 \\
\hline & $\%$ & 16,0 & 33,2 & 30,8 & 19,9 & 100 & 7,2 \\
\hline \multirow{2}{*}{$\begin{array}{l}\text { Korzystanie z literatury naukowej w języku innym } \\
\text { niż polski }\end{array}$} & $\mathrm{N}$ & 203 & 239 & 245 & 286 & 973 & 75 \\
\hline & $\%$ & 20,9 & 24,6 & 25,2 & 29,4 & 100 & 7,2 \\
\hline \multirow{2}{*}{ Korzystanie z e-zasobów bibliotek } & $\mathrm{N}$ & 299 & 241 & 240 & 199 & 979 & 69 \\
\hline & $\%$ & 30,5 & 24,6 & 24,5 & 20,3 & 100 & 6,6 \\
\hline \multirow{2}{*}{ Praca w bibliotece } & $\mathrm{N}$ & 278 & 302 & 277 & 114 & 971 & 77 \\
\hline & $\%$ & 28,6 & 31,1 & 28,5 & 11,7 & 100 & 7,3 \\
\hline \multirow{2}{*}{$\begin{array}{l}\text { Przygotowanie się do prowadzenia zajęć } \\
\text { dydaktycznych }\end{array}$} & $\mathrm{N}$ & 492 & 167 & 155 & 161 & 975 & 73 \\
\hline & $\%$ & 50,5 & 17,1 & 15,9 & 16,5 & 100 & 7,0 \\
\hline
\end{tabular}




\begin{tabular}{|c|c|c|c|c|c|c|c|}
\hline \multirow[b]{2}{*}{ Obowiązki studenckie } & \multicolumn{7}{|c|}{ Częstotliwość podejmowania obowiązków studenckich } \\
\hline & $\mathrm{N} / \%$ & nigdy & rzadko & czasami & regularnie & $\begin{array}{c}\text { suma } \\
\text { (bez braków) }\end{array}$ & braki \\
\hline \multirow{2}{*}{$\begin{array}{l}\text { Prowadzenie zajęć z zastosowaniem } \\
\text { nowoczesnych narzędzi }\end{array}$} & $\mathrm{N}$ & 529 & 168 & 176 & 98 & 971 & 77 \\
\hline & $\%$ & 54,5 & 17,3 & 18,1 & 10,1 & 100 & 7,3 \\
\hline \multirow{2}{*}{$\begin{array}{l}\text { Prowadzenie zajęć z zastosowaniem metody } \\
\text { e-learningu }\end{array}$} & $\mathrm{N}$ & 839 & 80 & 30 & 14 & 963 & 85 \\
\hline & $\%$ & 87,1 & 8,3 & 3,1 & 1,5 & 100 & 8,1 \\
\hline \multirow{2}{*}{ Pisanie artykułów teoretycznych } & $\mathrm{N}$ & 527 & 193 & 190 & 58 & 968 & 80 \\
\hline & $\%$ & 54,4 & 19,9 & 19,6 & 6,0 & 100 & 7,6 \\
\hline \multirow{2}{*}{$\begin{array}{l}\text { Pisanie artykułów o charakterze raportów } \\
\text { z badań }\end{array}$} & $\mathrm{N}$ & 595 & 150 & 127 & 94 & 966 & 82 \\
\hline & $\%$ & 61,6 & 15,5 & 13,1 & 9,7 & 100 & 7,8 \\
\hline \multirow{2}{*}{ Prowadzenie badań na potrzeby artykułów } & $\mathrm{N}$ & 519 & 180 & 138 & 130 & 967 & 81 \\
\hline & $\%$ & 53,7 & 18,6 & 14,3 & 13,4 & 100 & 7,7 \\
\hline \multirow{2}{*}{$\begin{array}{l}\text { Prowadzenie badań naukowych na potrzeby } \\
\text { projektów badawczych }\end{array}$} & $\mathrm{N}$ & 606 & 140 & 109 & 111 & 966 & 82 \\
\hline & $\%$ & 62,7 & 14,5 & 11,3 & 11,5 & 100 & 7,8 \\
\hline \multirow{2}{*}{ Uczestnictwo w zespołach badawczych } & $\mathrm{N}$ & 641 & 140 & 83 & 96 & 960 & 88 \\
\hline & $\%$ & 66,8 & 14,6 & 8,6 & 10,0 & 100 & 8,4 \\
\hline \multirow{2}{*}{$\begin{array}{l}\text { Uczestnictwo w konferencjach, seminariach } \\
\text { naukowych }\end{array}$} & $\mathrm{N}$ & 351 & 271 & 231 & 117 & 970 & 78 \\
\hline & $\%$ & 36,2 & 27,9 & 23,8 & 12,1 & 100 & 7,4 \\
\hline \multirow{2}{*}{$\begin{array}{l}\text { Wygłaszanie referatów na konferencjach, } \\
\text { seminariach }\end{array}$} & $\mathrm{N}$ & 662 & 133 & 110 & 66 & 971 & 77 \\
\hline & $\%$ & 68,2 & 13,7 & 11,3 & 6,8 & 100 & 7,3 \\
\hline \multirow{2}{*}{$\begin{array}{l}\text { Prezentacja plakatów na konferencjach, } \\
\text { seminariach }\end{array}$} & $\mathrm{N}$ & 789 & 80 & 53 & 44 & 966 & 82 \\
\hline & $\%$ & 81,7 & 8,3 & 5,5 & 4,6 & 100 & 7,8 \\
\hline \multirow{2}{*}{ Podejmowanie kwerend bibliotecznych } & $\mathrm{N}$ & 784 & 80 & 62 & 39 & 965 & 83 \\
\hline & $\%$ & 81,2 & 8,3 & 6,4 & 4,0 & 100 & 7,9 \\
\hline \multirow{2}{*}{ Konsultacje z pracownikami naukowymi } & $\mathrm{N}$ & 230 & 332 & 277 & 126 & 965 & 83 \\
\hline & $\%$ & 23,8 & 34,4 & 28,7 & 13,1 & 100 & 7,9 \\
\hline \multirow{2}{*}{ Działalność w kołach naukowych } & $\mathrm{N}$ & 584 & 165 & 115 & 99 & 963 & 85 \\
\hline & $\%$ & 60,6 & 17,1 & 11,9 & 10,3 & 100 & 8,1 \\
\hline \multirow{2}{*}{ Działalność w samorządzie studenckim } & $\mathrm{N}$ & 831 & 68 & 30 & 36 & 965 & 83 \\
\hline & $\%$ & 86,1 & 7,0 & 3,1 & 3,7 & 100 & 7,9 \\
\hline
\end{tabular}

Źródło: Opracowanie własne na podstawie przeprowadzonych badań.

Badani studenci regularnie:

- są obecni na wykładach (56,7\%),

- są obecni na ćwiczeniach (91\%),

- uczestniczą w zajęciach, na których obecność jest obowiązkowa (95,7\%),

- realizują zadania indywidualne, w ramach zajęć (58\%),

- realizują zadania zespołowe, w ramach zajęć (38,3\%),

- przygotowują się do udziału w zajęciach (44,8\%),

- przygotowują się do kolokwiów i egzaminów (75,1\%),

- czytają obowiązkową literaturę naukową (50\%), 
- korzystają z literatury naukowej w języku obcym, innym niż język polski - najczęściej jest to język angielski $(29,4 \%)$,

- biorą aktywny udział w zajęciach (43,6\%), co wydaje się nie do końca spójne z opiniami pracowników naukowych na temat aktywności studentów na prowadzonych przez nich zajęciach.

Badani studenci czasami:

- uczestniczą w zajęciach, na których obecność jest nieobowiązkowa (43,1\%),

- uczestniczą w zajęciach dodatkowych, nieobjętych programem studiów (39,7\%),

- czytają nieobowiązkową literaturę naukową (37,8\%),

- pracują w bibliotece $(28,5 \%)$.

Badani studenci rzadko:

- uczestniczą w wykładach otwartych (38,5\%),

- uczestniczą w dodatkowych kursach i szkoleniach (38,6\%),

- konsultują się z pracownikami naukowymi (34,4\%),

- korzystają z czasopism naukowych (33,2\%). Badani studenci nigdy nie:

- uczestniczą w zajęciach prowadzonych metodą e-learningu (47,2\%),

- korzystają z e-zasobów bibliotek (30,5\%),

- przygotowują się do prowadzenia zajęć dydaktycznych, w całości lub w części (50,5\%),

- prowadzą zajęcia z zastosowaniem nowoczesnych narzędzi i metody e-learningu $(87,1 \%)$,

- piszą artykułów teoretycznych (54,4\%),

- piszą artykułów o charakterze raportów z badań (61,6\%),

- prowadzą badań naukowych na potrzeby artykułów, referatów (53,7\%),

- prowadzą badań naukowych na potrzeby projektów (62,7\%),

- uczestniczą w zespołach badawczych (66,8\%),

- uczestniczą w konferencjach, seminariach naukowych (36,2\%),

- wygłaszają referatów na konferencjach, seminariach naukowych $(68,2 \%)$,

- prezentują plakatów na konferencjach, seminariach naukowych (81,7\%),

- podejmują kwerend bibliotecznych $(81,2 \%)$,

- działają w kołach naukowych (60,6\%),

- działają w samorządzie studenckim (86,1\%).

Badani studenci (bez rozróżnienie na studentów studiów I, II, III stopnia) regularnie i czasami podejmuje obowiązki, które mają charakter podstawowy i wystarczają do utrzymania statusu studenta. Badani studenci regularnie uczestniczą w ćwiczeniach i wykładach, szczególnie tych o charakterze obowiązkowym. W ramach zajęć na uczelni realizują wskazane im zadania indywidualne i zespołowe, przygotowują się do zajęć i czytają obowiązkową literaturę naukową. W toku pracy własnej i uczestnictwa w zajęciach przygotowują się do kolokwiów i egzaminów, których pozytywne wyniki pozwalają na utrzymanie statusu studenta. 
Badani studenci jedynie czasami uczestniczą w zajęciach nieobowiązkowych i czytają wskazaną im literaturę dodatkową. Również tylko czasami samodzielnie pracują w bibliotece nad postawionymi im problemami naukowymi. Badani studenci podejmują jedynie obowiązki, które są niezbędne do utrzymania statusu studentów. Zapominają o obowiązkach postrzeganych przez nich jako dodatkowe, nieobowiązkowe, więc niepotrzebne. Co za tym idzie, zaniedbują realizację niezwykle istotnych dla rozwoju naukowego obowiązków, takich jak uczestnictwo w konferencjach, dodatkowych kursach i szkoleniach, konsultacje $\mathrm{z}$ pracownikami naukowymi, korzystanie $\mathrm{z}$ czasopism naukowych, działanie w kołach naukowych i samorządzie studenckim, pisanie prac naukowych czy prowadzenia badań naukowych.

W opinii badanych studentów i pracowników naukowych studenci to grupa wyodrębniona z populacji młodzieży ze względu na wiek, podejmowane i realizowane obowiązki i zadania, zogniskowane wokół podstawowego celu, jakim jest zdobycie wykształcenia wyższego, a także role, podejmowane i realizowane w ramach przynależności do grupy społecznej studentów uniwersytetu, które wynikają z obowiązków i zadań oraz stanowią ich potwierdzenie.

\section{Podsumowanie}

Podsumowując, studenci uniwersytetu w opinii członków wspólnoty uniwersyteckiej, pracowników naukowych i studentów to grupa:

1. Duża i wewnętrznie zróżnicowana, co we współczesnych warunkach zdecydowanie negatywnie oddziałuje na jakość kształcenia. W tak dużej grupie studenckiej ciągle przybywa studentów niezaangażowanych i nieprzygotowanych do studiowania, którzy poświęcają na realizację obowiązków studenckich mniej niż 2 godziny dziennie (21,4\% badanych). W opinii pracowników naukowych 50\% studentów w ogóle nie powinno studiować. Mimo przewagi studentów przeciętnych i słabych w grupie studenckiej zauważa się studentów zdolnych, chętnych i zaangażowanych (około 10\%), którzy funkcjonują na przekór wskazanej masowości i wyrastają ponad przeciętną, wyższą na uniwersytecie niż na innych uczelniach wyższych.

2. Z jednej strony zintegrowana i wykazująca współpracę w czasie realizacji obowiązków studenckich, a z drugiej zindywidualizowana, a nawet rywalizująca o lepsze wykształcenie i co za tym idzie o miejsce w społeczeństwie. Współpraca ograniczona do realizacji obowiązków studenckich nie prowadzi do tworzenia się wspólnoty ludzi zintegrowanych wokół wiedzy i rzeczywistości uniwersyteckiej.

3. Wybrana w sposób celowy w zgodzie z własnymi potrzebami i życiowymi planami, co nie zmienia faktu, że na konkretnym kierunku mogą znaleźć się przypadkowe osoby, dla których był on kwestią spełnienia warunków rekrutacyjnych, a nie zainteresowań i zawodowych planów. W sytuacji gdy grupa studencka została wybrana w sposób ce- 
lowy i świadomy, charakteryzuje ją myślenie pragmatyczne oraz świadomość tego, co każdy student chce osiągnąć w toku i dzięki procesowi kształcenia. Przejawem myślenia pragmatycznego jest podejmowanie dodatkowego kierunku kształcenia (przez 19,1\% badanych), który w większość przypadków wybierany jest w sposób przemyślany i najczęściej należy do kierunków humanistycznych i społecznych.

4. Zintegrowana wokół poczucia tymczasowości, świadomości „tu i teraz” i strachu o to, jak będzie wyglądała przyszłość. Poczuciu tymczasowości towarzyszy odroczenie odpowiedzialności, często również w stosunku do realizacji obowiązków studenckich.

5. Ograniczająca do minimum nie tylko kontakty z innymi studentami, ale również z pracownikami naukowymi. Kontakty z pracownikami naukowymi charakteryzuje mniej formalny charakter, co z jednej strony może świadczyć o wzajemnym zaufaniu i pozytywnej atmosferze, a z drugiej wskazuje na postrzeganie pracowników naukowych tylko jako nauczycieli, którzy tracą autorytet naukowy.

6. Żyjąca w pośpiechu, któremu towarzyszy zniecierpliwienie i brak czasu, wynikający z podejmowania wielu różnych ról społecznych. Brak czasu, wskazany jako cecha studenckiej grupy społecznej, prowadzi do tego, że badani studenci poświęcają na studiowanie czas, który obiektywnie wydaje się być niewystarczający (2-4 godziny dziennie). Mimo zdawałoby się niewystarczającego czasu poświęcanego na realizację obowiązków studenckich, studenci uniwersytetu osiągają bardzo dobre wyniki w nauce i wysoką średnią ocen (4,5-5), co wskazuje na zmniejszenie wymagań w stosunku do grupy studenckiej i wyraźny spadek jakości kształcenia.

7. Wybierająca i z sukcesem realizująca obowiązki podstawowe, gwarantujące pozostanie na studiach i utrzymanie statusu studenta. Pozostałe obowiązki, postrzegane jako dodatkowe realizowane są rzadko i nieregularnie przez szczególnie zainteresowanych studentów.

Słowa kluczowe: studiowanie, studenci, role społeczne, uniwersytet 


\title{
STUDENTS AND THEIR BEHAVIOR IN THE CURRENT UNIVERSITY REALITY
}

\author{
Summary
}

Studying is formed by process of education and self - study. Studying is proceeding in connection with professional social roles, family social roles and community social roles. Studying is proceeding in connection with present university condition. University is a part of social reality, which is describing by international and connected with definite country acts of social becoming. University studying allows to identify students social group that is the part of article analysis.

The article is the research report (studies have been conducted in the oldest polish universities).

Quantitative and qualitative research is a part of pedagogy of higher education. Research conclusions are important for the whole society and every student because are connected with social roles activity in harmony with studying high quality.

Keywords: studying, students, social roles, university 